\title{
17 \\ Biogeography, Ecology, and Evolution of Deep Life
}

\author{
CARA MAGNABOSCO, JENNIFER F. BIDDLE, CHARLES S. COCKELL, \\ SEAN P. JUNGBLUTH, AND KATRINA I. TWING
}

\subsection{Subsurface Biomes and Their Inhabitants}

When we ponder the existence of life extending deep into Earth, a phrase from the movie Jurassic Park is often used: that "life finds a way." Numerous investigations into the continental and marine subsurface have shown that life indeed finds a way to exist deep into the subsurface, provided that physical influences, particularly heat, allow for the existence of biomolecules. In this chapter, we will review what is known about the biogeography, ecology, and evolution of deep life, acknowledging along the way that this field is rapidly developing with every new set of experiments and continued exploration.

The subsurface biosphere is loosely defined as the habitable region beneath the soil and sediments where the limits of habitability are typically defined by some physical process (also see Chapter 19, this volume). Current estimates of the habitable volume of the subsurface range from $\sim 2.0$ to $2.3 \times 10^{9} \mathrm{~km}^{3}$, or roughly twice the volume of our oceans (Table 17.1). This large biosphere is estimated to hold $\sim 70 \%$ of all bacterial and archaeal cells (Figures 17.1 and 17.2) and potentially over $80 \%$ all bacterial and archaeal species (for a review, see 1). A variety of habitats and sampling techniques to study the subsurface biosphere have been explored by scientists for nearly a century and are further described throughout this chapter (Sections 17.1.1-17.1.5; also see Figure 16.1 in Chapter 16, this volume).

\subsubsection{Continental Subsurface}

The earliest investigations into the deep subsurface biosphere were performed in oil fields and coal beds within the continental subsurface in the mid-1920s (13-15; for a review on the history of continental subsurface research, see 16). Since then, many different deep continental biomes have been explored, including (but not limited to) groundwater and deep aquifers, oil and gas reservoirs, deep bedrock, evaporite deposits, and subglacial ecosystems (Figure 17.1). Early reviews on the microorganisms inhabiting these subsurface biomes focused on cell numbers $(17,18)$, cultivation-based measurements of activity $(17,18)$, and/or large collections of clone libraries from amplified regions of the 16S rRNA gene $(19,20)$. 
Table 17.1 Recent estimates of subsurface habitable zones.

\begin{tabular}{llll}
\hline \hline Biome & Volume $\left(\mathrm{km}^{3}\right)$ & Definition & Refs. \\
\hline Continental subsurface & $7 \times 10^{8}$ & $\leq 85^{\circ} \mathrm{C}$ isotherm & $(1)$ \\
Continental subsurface & $1 \times 10^{9}$ & $\leq 122^{\circ} \mathrm{C}$ isotherm & $(1)$ \\
Groundwater & $2 \times 10^{7}$ & $\leq 2 \mathrm{~km}$ depth & $(2)$ \\
Sub-seafloor sediments & $3 \times 10^{8}$ & All sediments $(3-5)$ & $(6)$ \\
Marine sediment porewater & $8 \times 10^{7}$ & All sediments (3-5) & $(6)$ \\
Marine crust & $\sim 10^{9}$ & $\leq 120^{\circ} \mathrm{C}$ isotherm & $(7)$ \\
All subsurface & $\sim 2.0-2.3 \times 10^{9}$ & & \\
Oceans & $1 \times 10^{9}$ & All oceans & $(7)$ \\
\hline \hline
\end{tabular}

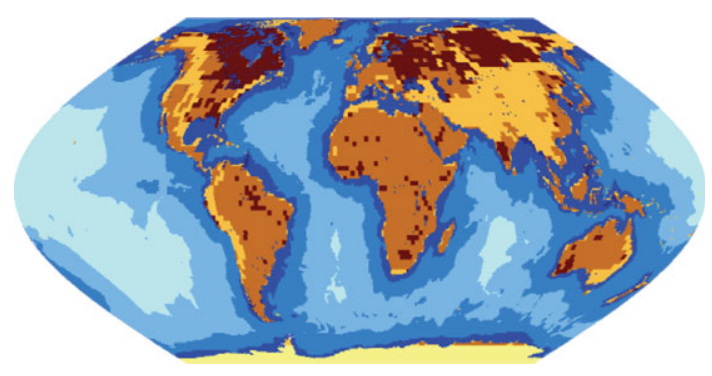

$$
\begin{aligned}
& \text { Subsurface cell concentrations (cells km }{ }^{-2} \text { ) } \\
& \square<10^{19} \square 10^{19}-10^{20} \square 10^{20}-10^{21} \square 10^{21}-10^{22} \square>10^{22} \\
& \square<10^{20} \square 10^{20}-10^{21} \square 10^{21}-10^{21.5} \square 10^{21.5}-10^{22}
\end{aligned}
$$

Figure 17.1 Map of sub-seafloor sediment and continental subsurface cell numbers. The distributions of bacterial and archaeal cells in sub-seafloor sediments (blues; adapted from Kallmeyer et al. (8)) and the continental subsurface (browns; adapted from Magnabosco et al. (1)) are shown. Uncertainties in cellular estimates of the marine crust $(1,7,9)$ prevent mapping the distribution of cells throughout the marine crust at this time.

Over the past decade, the applications of metagenomics and next-generation sequencing have allowed researchers to further examine the identities and lifestyles of organisms residing in the continental subsurface. The first deep subsurface metagenome was generated from DNA extracted from the fracture fluids of a 2.8-km deep borehole in South Africa (21) and revealed a "single-species ecosystem" containing a population of chemoautotrophic Firmicutes, "Candidatus Desulforudis audaxviator," capable of performing sulfate reduction and fixing nitrogen and carbon (further discussion in Chapter 18, this volume). Although the number of species observed in this early investigation and other subsurface clone libraries $(19,20)$ was low, next-generation sequencing has revealed that single-species continental subsurface ecosystems are an exception to an otherwise highly 


\section{Number of Prokaryotes}
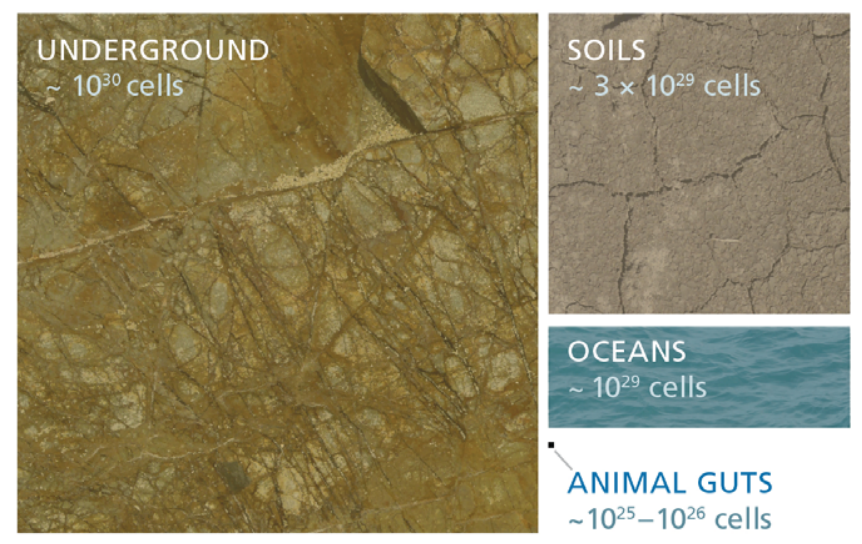

Figure 17.2 Estimated numbers of bacteria and archaea throughout various biomes. Cellular estimates for the subsurface $(1,8-10)$, soils $(11)$, oceans $(9,11)$, and animal guts $(9,12)$ are illustrated to show the relative sizes of each biome.

diverse subsurface biosphere (for a review, see 1). A large part of the increased $\alpha$-diversity is due to the observation of many low-abundance taxa in next-generation sequencing data sets. These low-abundance microorganisms, generally termed the "rare biosphere" (22), are now accepted as a common feature of environmental microbial communities and may persist in order to preserve a diverse collection of metabolic strategies for survival in changing environments.

Within the continental subsurface, natural fluctuations in fluid chemistries are just beginning to be understood (23); however, large disruptions to subsurface environments through human activities have been reported to dramatically alter continental subsurface communities (24-29). Events that have been shown to increase the overall salinity of deep fluids such as hydraulic fracturing (fracking) (30-36) and drilling (37) are often associated with decreases in $\alpha$-diversity and increases in halo-tolerant bacteria. More recently, an indepth analysis of the metabolic potential for 31 unique metagenome-assembled genomes (MAGs) showed that the persisting halo-tolerant bacteria and archaea were capable of fermenting chemical additives brought in during the injection process (26). A similar trend has been reported in the oil wells of the Enermark Field (Alberta, Canada). There, native oil phases support low-diversity communities of methanogens and acetogens (38), while emergent aqueous phases (oil + water) exhibit bursts in populations of sulfate-reducing Deltaproteobacteria that change the overall subsurface community composition $(39,40)$. These "blooms" of sulfate-reducing bacteria (SRB) in water-flooded reservoirs can dramatically raise concentrations of hydrogen sulfide $\left(\mathrm{H}_{2} \mathrm{~S}\right)$ due to their consumption of hydrocarbons coupled to the reduction of sulfate. Commonly referred to as reservoir souring, this microbial by-product can lead to corrosion of pipelines, plugging of oilbearing rock, and contamination of the extracted oil (41), but it can be controlled via the 
addition of higher-energy electron acceptors such as nitrate (42). On the other hand, the increased SRB activity and growth observed after $\mathrm{H}_{2}$ injection in the Opalinus clay (Switzerland) has been proposed as a way to control $\mathrm{H}_{2}$ generated in underground nuclear waste repositories (25).

In many of the aforementioned examples, it is difficult to determine whether or not the changes in community composition are driven by the introduction of foreign organisms or the expansion of a native member. Long-term monitoring of subsurface fluids in "underground labs" is beginning to reveal how these ecosystems change over time (23) and the variations between the attached and planktonic members of the microbial community (43). After nearly a century of research into life beneath the continents, it is now apparent that the continental subsurface is home to a wide variety of fluid chemistries and lithologies (44-46). A comparison of 326 bacterial and archaeal 16S rRNA gene surveys from a variety of continental subsurface environments revealed a correlation between community composition and sample lithology (1), yet the variety of microbial metabolisms encountered beneath the continents (e.g. 44,47-51), how these metabolisms arose, and the interactions between these organisms (52), viruses $(53,54)$, and the environment are just beginning to be understood.

\subsubsection{Sub-seafloor Sediments}

Early work on sub-seafloor sediments mainly focused on continental margins and quickly recognized a wide distribution of bacteria and archaea and an importance of heterotrophic metabolisms (55; as described in Chapter 16, this volume). In deeply buried sediments sampled through the scientific drilling program - currently the International Ocean Discovery Program (IODP) - microbes are responsible for large-scale geochemical shifts, including consumption of methane and sulfate (55-57). Further investigations have shown that below oceanic gyres, the deep biosphere may be an oxic environment and interact with deep hydrothermal recharging $(58,59)$. With the noted impacts of deep life on processes relating to global biogeochemistry, continued work is focusing on constraining the rates and limits of these processes (for further discussion on this topic, see Chapter 19, this volume).

Marine sediments are a heterogeneous environment and record Earth history along with the modern life that may be living in situ. Tremendous advances were made through the first drilling expedition to focus solely on the marine deep biosphere, Ocean Drilling Program Leg 201, which visited the Peru Margin in 2002. This expedition showed that cells increased in areas of potential geochemical energy (55), that archaeal cells were active and heterotrophic throughout the sediment column (59; Chapter 16, this volume), and that the metagenomic signature of sediments was distinct from any other sampled environment up to that time (60). This expedition also yielded the first metatranscriptome of marine sediments, which showed dominant transcripts for fermentation (61) and that SRB may invest in different cellular strategies based on energy availability (62). Investigations on the Gulf of Mexico (63), Nankai Trough (64,65), Guaymas Basin (66,67), Baltic Sea (68), and 
Shimokita Peninsula (69), among others, have shown that sub-seafloor microbial life is found wherever it can exist. The interplay of bacteria and archaea is still being investigated, as areas of the Andaman Sea contain no detectable archaea (70).

The establishment and propagation of the sediment-hosted deep biosphere is still under investigation, but likely includes a combination of selection from the surface environment (71) and persistence of cells with depth (72). What stimulates the deep biosphere, in addition to chemical interfaces, may include the continued influence of depositional conditions (68), tectonic activity (73), geological shifts under pressure (74), and the internal heating of Earth (75). It is still unknown exactly how the community in deep sediment responds to the stress of sedimentation. It is theorized that necromass (76) or radiolysis (77; Chapter 19, this volume) may help support deep communities. Evidence of subsurface acclimation to changing surface conditions exists, showing that the marine deep biosphere is responsive and may be capable of more activity than expected (77). Life in the deep marine biosphere has been reviewed extensively (78-81), and with new investigations underway, discoveries are still abundant.

\subsubsection{Oceanic Crust}

Despite the larger volume of the basaltic crust environment relative to marine sediments (Table 17.1), relatively little is known about the abundance and extent of microbial biomass in the deep oceanic basement because it is heterogeneous and largely inaccessible (81). Early investigations into microbial activity in the oceanic crust focused on the presence of microchannels and alteration patterns associated with DNA (e.g. 71,72), as the colocation of nucleic acids and unique microtextures (82) are taken together to represent biogenic alteration in basaltic rock. Overall, most biogenic alteration is restricted to the upper $250 \mathrm{~m}$ of the oceanic crust, corresponding to a predicted temperature range of $15-80^{\circ} \mathrm{C}$ (7). Sulfur and iron isotopic information suggests that the oxidation of basaltic crust mainly occurs in the relatively young ridge flank ( $<20$ million years old) (83). Combined, these observations have directed more recent and current IODP drilling expeditions to focus on searching for microbial life in relatively young oceanic crust.

\subsubsection{Warm Anoxic Basement}

The first investigation of the sediment-buried seafloor biosphere was conducted in 1998 by collecting fluids from an undersea Circulation Obviation Retrofit Kit (CORK) observatory in the 3.5-million-year-old basaltic crust of the Northwest Pacific Ocean's Juan de Fuca Ridge (JdFR) flank (84). In this pilot investigation, warm $\left(65^{\circ} \mathrm{C}\right)$ fluids originating from hundreds of meters below the seafloor were collected for gene cloning and sequencing and revealed a low-diversity environment with bacteria and archaea (no Eukarya) that was dominated by a Firmicute lineage later shown to be a close genomic relative of the terrestrial subsurface lineage " $\mathrm{Ca}$. Desulforudis audaxviator" $(21,84)$. Eight years after the initial CORK installation in the JdFR, scientists sampled a black rust scraping exposed 
to reducing fluids from the CORK observatory (85) and fluids emanating from an exposed rocky outcrop near the CORK observatory (84) and discovered an abundance of thermophilic lineages, indicating that the deep crustal biosphere is, at least in part, adapted to life at relatively high temperatures.

A new generation of borehole observatories equipped with microbiologically friendly sampling materials (86) was installed near the original JdFR CORK observatory in 2004. A 3-year sampling campaign at the JdFR identified low microbial cellular abundances $\left(\sim 10^{4}\right.$ cells $\left.\mathrm{mL}^{-1}\right)$ and revealed a microbial community whose major lineages changed each year (87). This dynamic subsurface community contrasts with deep marine sediment communities, which are stable on longer timescales and are more similar to communities observed at deep continental sites. In parallel to (87), the first successful retrieval of basement rocks for molecular microbiology analysis was recovered from JdFR (88) and identified methane- and sulfur-cycling bacteria and archaea that were most related to uncultivated marine sediment lineages. Incubations of rocks surrounding the CORK observatories $(89,90)$ revealed colonization of previously sterilized minerals by lineages that were more similar to the microorganisms identified in the crustal fluids than in collected rocks and consistent with a capacity for iron, nitrogen, and sulfur cycling. An incubation of mineral chips at the seafloor was less successful in reproducing the thermophilic and anoxic conditions found at depth, highlighting the difficulty of working in an extreme deep-sea sub-seafloor reducing environment (86).

In 2010, scientists sampled two boreholes separated by $\sim 67 \mathrm{~km}$ to investigate the temporal and spatial dynamics of microorganisms residing in JdFR basement fluids. Crustal fluids were retrieved from the location of the original CORK observatory and, for the first time, from younger $(1.2$ million years $)$ and cooler $\left(39^{\circ} \mathrm{C}\right)$ ocean crust. Gene cloning and sequencing revealed that the original CORK observatory was compromised in its ability to produce clean samples (91); this is perhaps expected given the 10+ years of corrosion that has occurred on the CORK parts exposed to both a reducing and oxic environment since installation (92). In contrast, samples collected from the cooler basement location contained evidence for Deltaproteobacteria involved in sulfur cycling and Clostridia related to " $\mathrm{Ca}$. Desulforudis." The identification of " $\mathrm{Ca}$. Desulforudis" in the cooler oceanic basement fluids suggests that relatives of " $\mathrm{Ca}$. Desulforudis audaxiator" inhabit a wider range of habitats than one might expect given its prevalence in the South African subsurface (Section 17.1.1). Combined with sulfate reduction rate measurements (93), these results indicate that anaerobic processes may play a major role in the degradation of organic matter in the upper oceanic crust.

Third-generation borehole observatories went online in JdFR in 2011, featuring the most microbiology-friendly components yet adapted. 16S rRNA amplicon sequencing of samples recovered from these observatories revealed an abundance of new lineages within Archaeoglobi, Aminicenantes, and Acetothermia that had not previously been identified in the oceanic crust $(93,94)$ and were later confirmed by metagenome sequencing and genome binning (95). From a functional perspective, microbial communities in the deep subseafloor appear similar to those found in terrestrial hot springs. Together, this work has 
helped to identify novel microbial diversity and stable members in the deep, warm, anoxic basement biosphere.

Although the JdFR is a popular location to study the warm, anoxic basement crust, a CORK observatory on the Costa Rica margin has been sampled for deep basement microbiology. Warm fluids $\left(58^{\circ} \mathrm{C}\right)$ collected from the CORK observatory revealed novel lineages of sulfur-oxidizing bacteria; however, little overlap was found between the Costa Rica site and JdFR (96), and this may, in part, be due to differences in fluid flow and organic matter delivery rates. Further experimentation and sampling from additional locations will be required to constrain the biogeographic patterns and to elucidate the ecology of microorganisms living in the ocean crust.

\subsubsection{Cold, Oxic Basement}

Exploration of the warm, anoxic deep basement biosphere has led the way in understanding the oceanic crust; however, the cold $\left(<20^{\circ} \mathrm{C}\right)$ and oxic basement rock is the more abundant of the sub-seafloor igneous biomes, and therefore of critical global biogeochemical importance. To this end, several CORK observatories were installed at North Pond, a sediment pond on the western flank of the Mid-Atlantic Ridge that overlies a hydrologically active ocean crust of $\sim 8 \mathrm{Ma}$ (97). When multiple depth horizons were sampled within the igneous basement, distinctive heterotrophic and autotrophic microbial communities largely composed of Proteobacteria were identified (98). Metagenomic sequencing and subsequent genome binning were used to identify members of the microbial community that were capable of exploiting hypoxic or anoxic conditions (99). Interestingly, enrichment cultures concocted with additions of nitrate and ammonia stimulated the microbial community, which together provide evidence for a heterogeneous functional population in the cold, oxic basement $(100,101)$. Additional investigations surveying a range of seafloor environment types (e.g. crustal ages, mineralogy, redox states, etc.) are needed to further refine global estimates of primary production in the oceanic crust.

\subsubsection{Ultra-basic Sites}

Serpentinization is a subsurface geochemical process that results in ultra-basic fluids $(\mathrm{pH}>10)$ and abiotically produces methane and small-chain hydrocarbons through Fischer-Tropsch-type synthesis (102-105). The hydrogen, methane, and abiotically generated organic molecules produced by serpentinization can serve as energy for microbial metabolisms in the otherwise energy-limited deep biosphere. One caveat, however, is that serpentinite fluids are depleted in electron acceptors (relative to electron donors) (106), meaning that this potential energy source may not be bioavailable in some environmental settings.

In the marine setting, the limitation of electron acceptors is alleviated as end-member serpentinite fluids emanating from hydrothermal vents mix with surrounding seawater. At the Lost City hydrothermal field (LCHF), vent fluids exhibit moderate temperature, high 
$\mathrm{pH}$, and millimolar concentrations of hydrogen and methane (104,107-109). Actively venting carbonate chimneys are dominated by a single taxon of methane-cycling archaea in the anoxic chimney interiors (110) and by methanotrophic and sulfur-oxidizing bacteria in the chimney exteriors (111). The older, inactive chimneys are much more diverse, hosting many bacterial taxa as well as anaerobic methane-oxidizing archaea (ANME) $(111,112)$. The microbial communities at LCHF are likely stimulated by, if not entirely dependent on, the $\mathrm{H}_{2}$, methane, and other carbon sources produced by serpentinization (113). Another site of marine serpentinization, Prony is a shallow marine hydrothermal vent located near New Caledonia that vents fluids elevated in hydrogen and methane (114). Both the $\mathrm{pH} 11$ fluids and chimneys from Prony exhibit similarly low archaeal diversity; however, they have a greater diversity of bacteria than Lost City, including the taxa Chloroflexi, Deinococcus-Thermus, Firmicutes, and Proteobacteria (115,116).

In the continental setting, serpentinization can take place underground in ophiolite complexes. Sampling of these subsurface processes often takes place at springs or pools, where the subsurface fluids come naturally to the surface. Various studies have used chemical proxies to differentiate subsurface, surface, and mixing-zone fluids $(117,118)$ and found consistent trends in the microbial communities of these different zones. The oxic/anoxic mixing zone of continental serpentinite sites is often dominated by a single Betaproteobacterium (106). Early diversity studies identified this organism as Hydrogenophaga (119-122). This bacterium was recently isolated from the Cedars, an ultra-basic site in northern California, resulting in a proposed name change to " $\mathrm{Ca}$. Serpentinomonas" (123). Multiple studies have shown that the Hydrogenophaga/" $\mathrm{Ca}$. Serpentinomonas" organisms from serpentinite sites have 99-100\% sequence identity (123-125). The Hydrogenophagal "Ca. Serpentinomonas" strains that dominate serpentine systems are alkaliphilic (optimum $\mathrm{pH}$ of 11) and autotrophic with growth on hydrogen, oxygen, and calcium carbonate (124). The more end-member serpentinite fluids tend to be host slightly higher diversity and contain anaerobes from the phyla Firmicutes $(106,120-122,124,126)$ and Chloroflexi (122) and the candidate division Parcubacteria $(122,126)$. These strong similarities in the community composition of these geographically distinct sites suggest that these organisms may be specially adapted to withstand the challenging conditions of the serpentinite environment.

Given the importance of methane-cycling microorganisms to marine serpentinite ecosystems $(111,113,127)$, scientists have wondered whether methane is of similar importance in continental settings. Previous diversity studies based on 16S rRNA gene amplicon data have suggested the presence of putative methane-cycling organisms at continental serpentinite sites $(121,122,126,128)$. More recently, metagenomic methods have been employed to look more deeply into this question $(129,130)$. Both metagenomic and experimental evidence for methanogenesis by members of the Methanobacteriaceae and methanotrophy by members of the Methylococcaceae were found in extremely low-biomass sample from the Ligurian ophiolite in Italy (129). At the Santa Elena ophiolite in Costa Rica, all of the genes for diverse methanogenesis pathways were present (e.g. acetoclastic, hydrogenotrophic, and from formate) in metagenomes from a $\mathrm{pH} 11$ serpentinite spring (130). 
The aforementioned studies were conducted by sampling the surface expression of a subsurface process through natural springs or pools. These features grant access to an otherwise inaccessible environment, but they represent opportunistic sampling at locations where the subsurface environment interacts with the surface. The Coast Range Ophiolite Microbial Observatory (CROMO) was established in northern California by drilling wells into the actively serpentinizing subsurface environment to access end-member fluids directly (131). A comparison of microbial communities from a wide range of geochemical gradients at CROMO found that the dominant taxa in the system were strongly correlated with $\mathrm{pH}$ and the concentrations of methane and carbon monoxide (124).

Studies have recently demonstrated that subsurface fluids and subsurface rocks from the same site exhibit differences in microbial community structure (43). To date, little research on serpentinite rocks has been published, save a study at the Leka ophiolite in Norway, which found that serpentinite groundwaters were dominated by the hydrogen-oxidizing Betaproteobacterium Hydrogenophaga (a close relative of the aforementioned " $\mathrm{Ca}$. Serpentimonas"), while mineral-associated communities contained microbes involved in nitrite, iron, manganese, and ammonium oxidation (132). At the Ligurian ophiolite in Italy, surface-exposed travertine deposits at serpentinite springs were investigated and archaeal species putatively involved in methane cycling and diverse bacterial species putatively involved in hydrogen oxidation were found, suggesting that these surface organisms could be fueled by deep serpentinization below (128). Additional studies are currently underway to investigate the microbial ecology of serpentinite rocks at continental $(131,133)$ and marine (134) sites of serpentinization. These studies, combined with those investigating the microbial ecology of serpentinite fluids, will give us a more complete understanding of life in the ultra-basic subsurface environment.

\subsubsection{Other Subsurface Environments}

Submarine volcanoes like the Suiyo (135) and Axial (136) Seamounts emit fluids that are at a lower $\mathrm{pH}$ than their surrounding seawater. These localities contain high amounts of $\mathrm{H}_{2} \mathrm{~S}$ and often harbor large populations of sulfur-oxidizing Epsilonproteobacteria. On the other hand, submarine mud volcanoes and cold methane seeps release large amounts of methane that fuel sizeable populations of ANME (125-127). On the continents, the Rio Tinto in Spain (137) is an acidic environment for which the subsurface microbial communities were investigated. The Mars Astrobiology Research and Technology Experiment (MARTE) project identified three zones within the Rio Tinto's subsurface: (1) a nearsurface to $\sim 30 \mathrm{~m}$ below sea level (mbsl) zone that supports fungal populations and is primarily driven by heterotrophy and aerobic respiration with seasonal rainfall; (2) a 30-43-mbls zone in which iron and sulfur oxidation of sulfide minerals occurs under aerobic conditions by aerobic iron and sulfur oxidizers; and (3) an anaerobic deep zone ( $>43 \mathrm{mbsl}$ ) that contains organisms inferred to be carrying out anaerobic iron and sulfur oxidation, with SRB potentially producing $\mathrm{H}_{2} \mathrm{~S}$ and thence pyrite by reaction with host rocks. 
While a diverse array of subsurface environments exists on our planet, it is important to consider the implications of the adaptations and lifestyles of subsurface organisms for the habitability of extraterrestrial subsurface environments. The surface of Mars is inhospitable today on account of desiccation, ultraviolet and ionizing radiation, and oxidants (138), yet the subsurface may have been more habitable throughout Martian history (139). In the outer solar system, the detection of hydrogen and silica in fluids ejected from the south polar of Saturn's icy moon Enceladus suggests fluid-rock interaction within that moon, showing that deep subsurface rock-water interactions on Earth may provide analogous insights into the limits of habitability of these environments (140). While the constraints on the fluid compositions of these extraterrestrial environments are poor, the lack of a connection to a surface photosynthetic biosphere means that these environments are likely to be carbon poor and that the primary available redox couples are chemolithotrophic.

All extraterrestrial environments receive an infall of meteoritic material, such as cometary or carbonaceous chrondrite material as well as endogenous reduced organic material. A crude calculation estimates the infall of unaltered carbon on Mars to be $\sim 16 \mathrm{~g}$ of unaltered carbon $\mathrm{km}^{-2}$ year $^{-1}(141)$, although much of this is in recalcitrant polycyclic aromatic hydrocarbon material. Compared to the estimated net primary productivity on Earth $\left(\sim 2 \times 10^{8} \mathrm{~g} \mathrm{~km}^{-2}\right.$; 142 ), about seven orders of magnitude more carbon is available to ultimately make its way into the deep subsurface of Earth than of Mars. However, as in Earth's deep subsurface, radiolysis, serpentinization, and reduced volcanic gases may provide $\mathrm{H}_{2}$ as an electron donor largely independent of carbon availability (143). In the case of icy moons, the quantity of exogenous carbon that is recirculated into the subsurface oceans is unknown (e.g. 144), although detection of low- and high-molecular-weight carbon compounds in the fluids of Enceladus (145) could suggest an endogenous source of carbon, such as from a core with a chondritic composition. Although there is much to be learned about extraterrestrial deep subsurface environments, it is clear that a growing knowledge of the physicochemical conditions in the terrestrial deep subsurface and how they restrict life (Section 17.3.1), as well as the role of the carbon cycle in constraining energy availability (Chapter 19, this volume), provides a foundation not only for understanding extraterrestrial environments, but also for prioritizing the measurements required to better constrain their habitability.

\subsection{Global Trends in Subsurface Microbiology}

While the previous section focused on the distribution of life throughout the subsurface, this section provides a more comprehensive overview of the organisms residing within the deep subsurface and their interactions between one another.

\subsubsection{Archaea and Bacteria}

The deep ocean is typically enriched in archaeal cells, but nearly all other marine environments show a dominance of bacterial lineages (146). This was initially challenged by 
observations on the Peru Margin, which showed active archaeal cells in dominant abundances (147). Further investigation of archaeal intact polar lipids showed that archaeal lipid dominance tracked with organic carbon content in sediments (148); however, it was later shown that these lipid profiles may be problematic due to long-lived phospholipids (149) and that initial measurements should be revised. Subsequent work and methodological clarifications (150) have suggested that archaea and bacteria may have equal abundances in some sediments, yet a range of conditions persist, particularly in locations where no archaea have been found (70). Recent evidence suggests that initial bioturbation may be one of the most significant impacts on archaeal versus bacterial dominance in sediments (151).

Under the continents, the majority of sample sites show a dominance of chemotrophic bacterial lineages (1). Despite small numbers, hydrogenotrophic methanogens are frequently detected, and there is an important link between the available dissolved inorganic $\mathrm{C}$ pool and the larger bacterial community $(152,153)$. In the Olkiluoto underground laboratory (Finland), populations of methane-oxidizing archaea become the dominant members of the microbial community within a sulfate-methane mixing zone located around 250-350 mbsl (45). Although subsurface methanogens and ANME have been relatively well characterized, other members of the continental subsurface archaeal communities are less understood. Targeted analysis on archaeal bins and single-cell genomes recovered from the continental subsurface are providing a new, in-depth look at archaea that were previously recognized only by their 16S rRNA gene sequences (for more details, see Chapter 18, this volume).

A notable example is the recent effort to characterize members of the South African Gold Mine Miscellaneous Euryarchaeal Group (SAGMEG) that are frequently reported in both marine and continental subsurface 16S rRNA gene surveys (154). The genomes of four SAGMEGs were recovered from diverse environmental samples and compared, revealing that these organisms most likely derive energy through the oxidation of carbon monoxide coupled to water or nitrite reduction. The comparative analysis also improved the phylogenetic placement of SAGMEG, resulting in a proposed reclassification of SAGMEG to a new group, "Hadesarchaea." The prevalence of "Hadesarchaea" and other candidate phyla (155) within subsurface environments is rapidly expanding our understanding of microbial diversity and changing the way we view the tree of life (156).

\subsubsection{Subsurface Isolates and Interactions}

While the number of novel taxa identified through DNA sequencing continues to grow at a rapid rate, the isolation and study of subsurface taxa lag behind. An important by-product of the isolation of subsurface microorganisms is the ability to test bacterial and archaeal responses to extreme temperature, pressure, $\mathrm{pH}$, and salinity (see further discussion in Section 17.3), and also sense their contributions to carbon cycling in the deep subsurface (Chapter 18, this volume). A notable example is the isolation and study of the thermoacidophilic archaeon, Aciduliprofundum boonei, which was isolated from the hydrothermal 
fluids of the East Pacific Rise and Eastern Lau spreading center (157). A. boonei is capable of growing in fluids as acidic as $\mathrm{pH} 3.3$ and temperatures as high as $75^{\circ} \mathrm{C}$. Due to its prevalence in hydrothermal vent $16 \mathrm{~S}$ rRNA gene surveys, the isolation and study of $A$. boone $i$ has been particularly informative to the study of thermoacidophilic archaea and sulfur and iron reduction in the subsurface.

While isolates provide tremendous insights into the physiology of microorganisms, the syntrophic and symbiotic relationships between microorganisms are ignored. Syntrophic interactions and interconnected metabolisms, however, are commonly cited as important components of subsurface ecology $(47,52)$. One of the most well-studied examples of subsurface syntrophy is the partnership between ANME and SRB $(52,158,159)$ (for more details, see Chapter 18, this volume). Other examples include methogens and ANME (52), methanogens and $\mathrm{H}_{2}$ producers like Thermococcus paralvinellae (160), and sulfur oxidizers and SRB (52). In the oceanic crust, a spatial-temporal comparison of MAGs assembled from the fluids of North Pond on the Mid-Atlantic Ridge revealed a high degree of functional redundancy despite changes in community membership, suggesting that a consistent and stable set of metabolic interactions is necessary for life to succeed in North Pond (99). On the other hand, subsurface symbionts are less understood; however, symbiotic relationships between nanoarchaea and autrophic " $C a$. Altiarchaeaum sp." in the subsurface fluids of Crystal Geyser, Utah, were recently proposed due to co-occurrence patterns observed from metagenomic data (161).

\subsubsection{Subsurface Eukaryotes}

The discovery of the nematode, Halicephalobus mephisto, within the South African subsurface revealed that complex, multicellular organisms are able to withstand the pressure, isolation, and temperature of the subsurface over $1 \mathrm{~km}$ underground (162). A recent effort to sequence the genome of $H$. mephisto revealed that an expanded repertoire of $70-\mathrm{kDa}$ heat-shock protein (Hsp70) may be an important attribute of the H. mephisto genome, aiding in the nematode's tolerance to elevated temperatures at depth (163). Following the discovery of subsurface Nematoda, other multicellular eukaryotes including Platyhelminthes, Rotifers, Annelids, and Arthropoda and unicellular Protozoa and Fungi have been identified at depth in the South African subsurface (164). Recent efforts to identify the source and transport of these eukaryotes underground point to freshwater sources and seismic activity (165).

While only a handful of subsurface sites have identified viable multicellular life, several continental $(164,166-170)$ and marine subsurface (171-175) localities have identified diverse populations of fungi through sequencing and isolation. While the means of survival for subsurface fungi are still unknown, many believe subsurface fungi play a role in the degradation and recycling of nutrients in the subsurface via fermentation. It has been proposed that hydrogenosome-containing anaerobic fungi may produce $\mathrm{H}_{2}$ during carbohydrate degradation and subsequently form syntrophic interactions with methanogens and/ or SRB $(176,177)$. 


\subsubsection{Subsurface Viruses}

Viruses in the open ocean are now recognized as important players in marine biogeochemical cycles, initiating an estimated $10^{23}$ viral infections a second (178) and delivering up to $150 \mathrm{Gt}$ of $\mathrm{C}$ to the photic zone each year through cell lysis (179). The role of viruses and their interactions with subsurface life, however, are less understood (for reviews dedicated to the topic of subsurface viruses, see 180-182). Many of the earliest investigations into subsurface viruses focused on enumeration-based methods such as virus particle-tocell ratios (54,183-185). In the marine environment, viruses are $2-25$ times more abundant than marine bacteria (186), but in subsurface settings, this ratio can be as large as 225:1 (185).

Different hypotheses have been proposed to explain the elevated virus-to-cell ratios in the subsurface, and many have suggested that viral predation is an active process in the subsurface $(180,182)$. Evidence of viable lytic viruses (53), active infections via single-cell sequencing (187), and acquired viral immunity via CRISPR have been reported $(21,26,188)$. On the other hand, long-term preservation of viral particles and low to no rates of viral infections in diffusion-limited marine sediments like the South Pacific Gyre have been proposed to explain elevated virus-to-cell ratios in the subsurface (185).

Although there has been some experimental work to characterize the host range and infection frequency of subsurface viruses $(53,188)$, the majority of these viruses are still uncharacterized (189). Advances in sampling procedures and sequencing technologies are improving the genetic characterization of viruses through (meta)genomics (190) and metatranscriptomics (189). As we continue to learn more about subsurface viruses, an important question will be how viruses influence the evolution of life in the subsurface.

\subsection{Subsurface Ecology and Evolution}

The abundance and diversity of life in surface environments are constrained by physical and chemical extremes such as temperature, pressure, salinity, and $\mathrm{pH}$ (Figure 17.3).

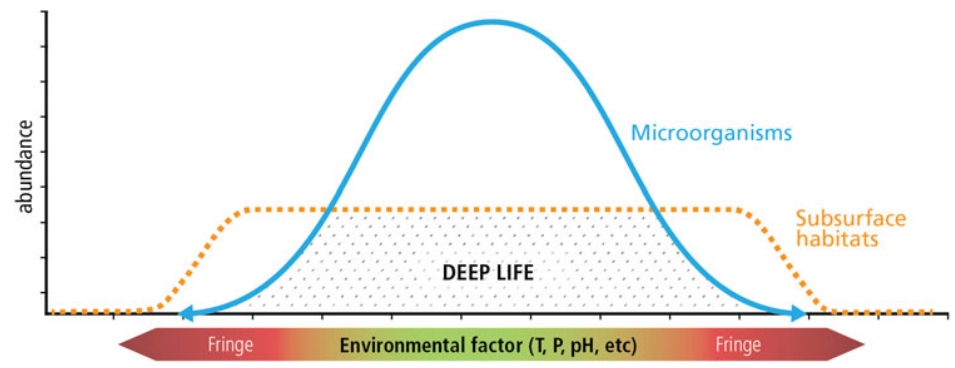

Figure 17.3 Schematic of the distribution of microbial life throughout the subsurface. An illustration of the abundance of microorganisms (blue) and subsurface habitats across a gradient of environmental factors $(\mathrm{x}$-axis; green $=$ habitable, red $=$ uninhabitable $)$ is shown. The overlap of the two curves represents the abundance and distribution of deep life. 
As only a few subsurface sites have been sampled near these extremes, documented examples of correlations between these extremes and subsurface life are limited. However, numerous experiments and models have provided additional insights into the physical pressures of life underground.

\subsubsection{Physical Extremes in the Deep Subsurface}

\subsubsection{Diffusivity}

As a first-order problem, some subsurface environments may be physically restrictive to organisms. Low porosity has been hypothesized to be a limit to life in some environments, an example being the low-porosity Clay Mesa shales that exhibit lower cellular abundances than the adjoining sandstones (191). At sufficient depth, high pressures and small particle sizes $(\sim 1 \mu \mathrm{m}$ or less) are likely to limit physical space and fluid movement (192). In cases where fracturing of deep subsurface substrates has occurred, these restrictions may be overcome. Cockell et al. (193) report an increase in cell abundance in the deep subsurface of the Chesapeake Bay meteorite impact structure and suggest that increases in porosity and fracturing of the rock in the impact-derived suevite layer increase both pore space and potentially fluid flow for microbial growth (193). When sufficient porosity is available, many subsurface environments are found to be energy restricted (for an in-depth discussion of the energy limitation problem, see Chapter 19, this volume).

Among the early successes in understanding how diffusivity influences microbial diversity are the microbial transport experiments performed at the US Department of Energy's field site in Oyster, Virginia (for a review on this topic, see 194). Experiments at the South Oyster Site highlighted the variability in attachment rate of microorganisms due to differences in surface charge and the importance of hydraulic conductivity to transport. More recent work has explored how endospores can be released from the subsurface and transported throughout the marine environment $(195,196)$, with current efforts focused on understanding how these processes influence biogeographic patterns in the subsurface.

\subsubsection{2 $\mathrm{pH}$}

In environments where space and energy are permissive for growth, other physical and chemical extremes may exert an influence on life, although many of these extremes are poorly studied. As with surface environments, there is no known subsurface environment where $\mathrm{pH}$ is known to limit life as a sole stressor. In hydrothermal vent environments, $\mathrm{pH}$ values as low as 1.6 are reported (197), although the movements of fluids though these systems make it difficult to determine long-term in situ $\mathrm{pH}$ values. The lowest growth of a subsurface isolate (A. boonei at $\mathrm{pH} 3.3$; 157) may not be the lowest $\mathrm{pH}$ limit of subsurface life. Alkaline environments are generated in the subsurface (see Section 17.1.4 for more details), such as during serpentinization of ultramafic rocks, which generates $\mathrm{pH}$ values greater than 12 (198). Isolates from the continental subsurface can grow at these extremes. 
Although cell numbers in the hyperalkaline Chamorro Seamount were found to decline in regions with a $\mathrm{pH}$ greater than 11 (199), there is no definitive evidence that $\mathrm{pH}$ alone limits growth.

\subsubsection{Salinity}

The isolation of halophiles from deep-sea environments (200) shows that salt-tolerant organisms can be found in the deep subsurface. Sodium chloride solutions with a water activity $>0.75$ are unlikely to act as limits to life in the deep subsurface. However, solutions of other salts, such as $\mathrm{MgCl}_{2}$, which can have water activities below the limit for life and potentially exert chaotropic effects, can potentially act as limits to life in deep subsurface $\mathrm{MgCl}_{2}$-rich brines (201). In the continental deep subsurface, evaporites at $1 \mathrm{~km}$ depth in the Boulby Mine (Zechstein sequence) have been observed to produce solutions with a water activity of 0.56 , below the limit for life and at which no life was detected (221). Deep subsurface evaporites may therefore contain habitats where salinity extremes limit life. These findings were obtained due to Deep Carbon Observatory support for metagenome sequencing of DNA purified and extracted from the evaporitic brines. The metagenomes have also yielded insights into carbon cycling in deep subsurface evaporites. For example, complete pathways for autotrophy were absent, but many complete pathways for metabolism of carbohydrates, amino acids, and other organic molecules were found, suggesting that the communities in the Zechstein sequence use either carbon derived from surface photosynthetic carbon entrained in surface-derived fluids or subsurface hydrocarbons (221).

\subsubsection{Temperature}

Because of the geothermal gradient, temperature is a ubiquitous extreme in the deep subsurface. Geothermal gradients can be extreme, such as in geothermally active regions (e.g. Yellowstone National Park), where the temperature may exceed the upper temperature limit for life (currently $121^{\circ} \mathrm{C}$ ) within centimeters. On the other hand, geothermal gradients at subduction zones may be $\sim 7^{\circ} \mathrm{C} \mathrm{km}^{-1}$, resulting in a theoretical $121^{\circ} \mathrm{C}$ isotherm of $\sim 17 \mathrm{~km}$ (202). The temperature at which natural communities of organisms are limited is not known. Investigations of deep subsurface marine sediments suggest that cell abundances drop to below detectable levels in sections corresponding to hyperthermophilic growth at less than the $121^{\circ} \mathrm{C}$ isotherm (203). A study of the Middle Valley sediments over an inactive hydrothermal sulfidic vent (Ocean Drilling Program (ODP) site 1035) showed that cell abundances dropped to below detection when temperatures were in the range $80-110^{\circ} \mathrm{C}$ at $70-170 \mathrm{~m}$ below seafloor (mbsf) (204). A temperature limitation-induced limit to life was similarly suggested for an active hydrothermal system (ODP legs 139 and 169), where cell abundances were found to increase laterally away from the vent, but to decrease substantially with depth and falling below detection at 20-25 mbsf (204).

In addition to temperature extremes, the limits of life may additionally be restricted by energy limitations or the imposition of other stressors (e.g. salinity or extreme $\mathrm{pH}$ ), making 
the limit lower than laboratory-determined investigations. However, one should also note that stressors do not always work in synergy to limit life. High pressure was found to shift the upper temperature limit of Desulfovibrio indonesiensis from $48^{\circ} \mathrm{C}$ to $50^{\circ} \mathrm{C}$ in the laboratory (192). Nevertheless, the lower cell abundances reported in numerous subsurface environments at temperatures that exceed $\sim 70^{\circ} \mathrm{C}$ compared to more mesophilic temperatures generally support the hypothesis that temperatures limit the deep biosphere in a region consistent with the upper temperature limits recorded for laboratory-grown strains.

\subsubsection{Adaptations for Survival at the Extremes}

The biochemical and physiological adaptations of organisms in the deep subsurface to physical and chemical extremes such as $\mathrm{pH}$ have not been well studied. In principle, there seems no reason to expect that adaptations to extremes such as $\mathrm{pH}$ would not be similar to the same adaptations observed in surface-dwelling organisms (e.g. transmembrane proton pumping as a means to regulate $\mathrm{pH} ; 205,206$ ).

However, of the range of physical parameters that can potentially influence deep subsurface life, high pressure is a ubiquitous condition $(207,208)$. High pressure will occur in combination with other stressors encountered in specific environments, so that understanding the limits of life under high pressure in combination with other extremes is paramount to knowing the role of pressure in defining the limits to life in the subsurface (Figure 17.3).

The adaptations to high pressure and combinations of high pressure with other extremes have received some attention. A study of $D$. indonesiensis revealed adaptations in the cellular lipids (192). High temperature was found to reduce the proportion of unsaturated lipids, presumably to enhance membrane packing. Although high pressures might be expected to act antagonistically to reduce membrane fluidity, chain length was found to increase and branching was found to decrease membrane fluidity, suggesting that alterations of saturation, fatty acid length, and branching are employed to allow adaptation to both high temperatures and pressures.

\subsubsection{Evolution of Deep Life}

Mutation, natural selection, gene flow, and genetic drift are generally considered to be the main drivers of evolution on our planet. For deep life, the origins and evolution of subsurface life remains an open question. While phylogenetic methods are essential for inferring the evolutionary history of genes and species, metagenomic and single-cell studies $(26,99,209-212)$ are beginning to provide new insights into the evolution of deep life.

In the subsurface, mutations - changes in the nucleotide sequence of a genome - are typically identified as mismatches observed during the alignment of metagenomic reads to a reference or consensus genome. Recently, scientists investigating the sediments of 
Aarhus Bay (210) and the hydrothermal fluids of Von Damm and Piccard in the MidCayman Rise (211) used sequence alignment methods to identify mutations within populations of microorganisms derived from various depths and/or habitats. To evaluate whether or not these populations were under positive or purifying selection, both studies compared the ratio of nonsynonymous and synonymous mutations $\left(\mathrm{K}_{a} / \mathrm{K}_{s}\right)$ in proteincoding sequences. With the exception of Piccard, these subsurface sites did not exhibit an elevated $\mathrm{K}_{a} / \mathrm{K}_{s}$, indicating that the majority of observed genetic changes were silent mutations and that the dominant evolutionary process was purifying selection (the removal of deleterious mutations over time) rather than positive selection (when beneficial mutations arise and sweep the population). These observations are consistent with more general studies that indicate that purifying rather than positive selection is responsible for the majority of diversity patterns we see within populations of microorganisms (213-215).

In addition to single-nucleotide changes, entire genes and cassettes of genes can be transferred from one population to another via horizontal gene transfer (HGT), an example of gene flow. HGTs are best identified through genomic and phylogenetic comparisons and play an important role in bacterial and archaeal evolution. A biofilm metagenome from the LCHF identified increased abundances of transposases relative to surface metagenomes, suggesting that HGT is an important evolutionary process in this system (216). In the continental subsurface, it has been shown that populations of subsurface bacteria have acquired horizontally transferred metabolic genes that distinguish them from that their surface- and sub-seafloor sediment-based relatives $(21,43,84)$. A comparison of 11 Thermotoga maritima-like genomes from surface marine sites in the Kuril Islands, Italy, and Açores and subsurface oil reservoirs in Japan and the North Sea revealed that these closely related organisms exhibit high amounts of gene flow between populations, suggesting that these T. maritima-like organisms are readily migrating to and from oil reservoirs around our planet (209).

While T. maritima-like organisms and the endospores described in Section 17.3.1.1 may readily move between surface and subsurface habitats, other subsurface populations may not migrate as easily. For sub-seafloor sediments, low diffusivity likely inhibits movement between the deepest sediment layers and the surface (210). Low replication rates, small population sizes, and restricted mobility may indicate that genetic drift, or the changes in genotype frequencies due to random events, may be a stronger driver of evolution than natural selection. The founder effect is a particularly interesting case of genetic drift in the context of sub-seafloor evolution. Here, a heterogeneous population gets divided into small populations of migrants due to stochastic processes. By chance, some of the migrant populations will exhibit low amounts of genetic variability and, over time, may look very different from the parent population.

While the interplay between these evolutionary processes continues to be an active field of subsurface research, additional advances have been made to understand the molecular mechanisms that lead to the diversity we observe. In addition to replication error, DNA damage and erroneous repair, and HGT, diversity-generating retroelements (DGRs) have 
been found to play an important role in the diversification of tail fiber ligand-binding domains in subsurface archaea (217) and a variety of protein targets in subsurface candidate phyla (218). DGRs create site-specific protein hypervariability through a process known as "mutagenic retrohoming" and are especially interesting in the context on subsurface diversification as they create diversity without cell replication or division. As evolutionary research continues in the subsurface, an important step will be to consider the roles that these processes play in the context of the energy, spatial, and population-level limitations each environment provides.

\subsection{Conclusion}

While much is still unknown, global initiatives like the Census of Deep Life (CoDL; https://vamps2.mbl.edu/portals/CODL) and IODP Expedition 370 (www.jamstec.go.jp/ chikyu/e/exp370) are currently generating large data sets to better characterize the biodiversity and limits to life in the subsurface. Already, the CoDL has coordinated the sequencing of over 600 subsurface samples from a wide variety of subsurface habitats, and the scientists of IODP Expedition 370 have collected 112 cores (equivalent to 577.85 $\mathrm{m}$ ) across the sediment-basalt interface. Although precautions and methodological improvements have been utilized in these important programs, major challenges such as changes in sequencing technology and contamination from the surface still exist. Similar to the efforts of the US Department of Energy, US Geological Survey, and US Environmental Protection Agency to identify indigenous subsurface microbial communities in the mid1980s (219), a major challenge will be the characterization of authentic and contaminating organisms. However, while Phelps and colleagues focused on the infiltration of drilling fluids into native samples (219), the current challenge is to remove contaminating DNA sequences from the surface and confounding factors from statistical analyses. Early work by Sheik et al. provides an interpretable outline of best practices for identifying and removing contaminating sequences from subsurface $16 \mathrm{~S}$ rRNA gene data sets (220). The remarkable progress since the first deep subsurface metagenome was sequenced a decade ago (21) highlights the extraordinary potential to advance our understanding of the subsurface biogeography, ecology, and evolution, with countless new discoveries awaiting on the made.

\section{Acknowledgments}

We thank Josh Wood for illustrating Figures 17.2 and 17.3 and Rob Pockalny for assisting in the preparation of the map in Figure 17.1. We also thank R Anderson, the Center for Dark Energy Biosphere Investigations (C-DEBI), the Flatiron Institute Center for Computational Biology (CCB), and participants of the C-DEBI/CCB Evolution Workshop funded by NSF award OIA-0939564 and the Simons Foundation for insightful discussions surrounding the topic of microbial evolution in the deep subsurface. 


\section{Questions for the Classroom}

1 What are the subsurface biomes and how do they vary?

2 What limits cellular abundances in the continental subsurface and marine subsurface?

3 What are some common themes between the continental and marine subsurface biospheres?

4 Where would heterotrophic lifestyles, autotrophic lifestyles, and a combination (i.e. metabolic versatility) be predicted in the subsurface?

5 What methods are available to study subsurface life and how do they vary?

6 What are the physical limits to life on Earth?

7 What might deep life tell us about life on other planets?

8 What are the mechanisms of evolutionary change? How would one identify them?

\section{List of Online Resources}

Maps of subsurface studies and cell numbers: https://caramagnabosco.shinyapps.io/ SubsurfaceBiologicalStudies.

C-DEBI BCO-DMO data portal: www.bco-dmo.org/program/554979.

\section{References}

1. Magnabosco C, Lin L-H, Dong H, Bomberg M, Ghiorse W, Stan-Lotter H, et al. The biomass and biodiversity of the continental subsurface. Nat Geosci. 2018;11(10):707.

2. Gleeson T, Befus KM, Jasechko S, Luijendijk E, Cardenas MB. The global volume and distribution of modern groundwater. Nat Geosci. 2016;9(2):161-167.

3. Divins DL. Total Sediment Thickness of the World's Oceans and Marginal Seas. NOAA National Geophysical Data Center. www.ngdc.noaa.gov/mgg/sedthick/ sedthick.html, 2002.

4. Laske G, Masters G. A global digital map of sediment thickness. Eos Trans AGU. 1997;78:F483.

5. Whittaker JM, Goncharov A, Williams SE, Müller RD, Leitchenkov G. Global sediment thickness data set updated for the Australian-Antarctic Southern Ocean. Geochem Geophys Geosystems. 2013;14(8):3297-3305.

6. LaRowe DE, Burwicz E, Arndt S, Dale AW, Amend JP. Temperature and volume of global marine sediments. Geology. 2017;45(3):275-278.

7. Heberling C, Lowell RP, Liu L, Fisk MR. Extent of the microbial biosphere in the oceanic crust. Geochem Geophys Geosystems. 2010;11(8):Q08003.

8. Kallmeyer J, Pockalny R, Adhikari RR, Smith DC, D'Hondt S. Global distribution of microbial abundance and biomass in subseafloor sediment. Proc Natl Acad Sci. 2012;109(40):16213-16216.

9. Bar-On YM, Phillips R, Milo R. The biomass distribution on Earth. Proc Natl Acad Sci. 2018;115(25):6506-6511.

10. Parkes RJ, Cragg B, Roussel E, Webster G, Weightman A, Sass H. A review of prokaryotic populations and processes in sub-seafloor sediments, including biosphere: geosphere interactions. Mar Geol. 2014;352:409-425. 
11. Whitman WB, Coleman DC, Wiebe WJ. Prokaryotes: the unseen majority. Proc Natl Acad Sci. 1998;95:6578-6583.

12. Kieft TL, Simmons KA. Allometry of animal-microbe interactions and global census of animal-associated microbes. Proc Biol Sci. 2015;282(1810):20150702.

13. Bastin ES, Greer FE, Merritt CA, Moulton G. The presence of sulphate reducing bacteria in oil field waters. Science. 1926;63(1618):21-24.

14. Ginsburg-Karagitscheva TL. Microbiological research in the sulphurous and salty waters of Apsheron. Azerb Neft Khozjajstvo. 1926;6-7.

15. Lipman CB. The discovery of living microrganisms in ancient rocks. Science. 1928;68(1760):272-273.

16. Onstott TC. Deep Life: The Hunt for the Hidden Biology of Earth, Mars, and Beyond. Princeton University Press, 2016.

17. Onstott TC, Phelps TJ, Kieft T, Colwell FS, Balkwill DL, Fredrickson JK, et al. Enigmatic Microorganisms and Life in Extreme Environments. Kluwer Academic, 1999.

18. Pedersen K, Ekendahl S. Distribution and activity of bacteria in deep granitic groundwaters of southeastern Sweden. Microb Ecol. 1990;20(1):37-52.

19. Fredrickson JK, Balkwill DL. Geomicrobial processes and biodiversity in the deep terrestrial subsurface. Geomicrobiol J. 2006;23(6):345-356.

20. Gihring TM, Moser DP, Lin L-H, Davidson M, Onstott TC, Morgan L, et al. The distribution of microbial taxa in the subsurface water of the Kalahari Shield, South Africa. Geomicrobiol J. 2006;23:415-430.

21. Chivian D, Brodie EL, Alm EJ, Culley DE, Dehal PS, DeSantis TZ, et al. Environmental genomics reveals a single-species ecosystem deep within Earth. Science. 2008;322:275-278.

22. Sogin ML, Morrison HG, Huber J A, Mark Welch D, Huse SM, Neal PR, et al. Microbial diversity in the deep sea and the underexplored "rare biosphere". Proc Natl Acad Sci. 2006;103(32):12115-12120.

23. Magnabosco C, Timmers PHA, Lau MCY, Borgonie G, Linage-Alvarez B, Kuloyo $\mathrm{O}$, et al. Fluctuations in populations of subsurface methane oxidizers in coordination with changes in electron acceptor availability. FEMS Microbiol Ecol. 2018;94: fiy089.

24. O'Mullan G, Dueker ME, Clauson K, Yang Q, Umemoto K, Zakharova N, et al. Microbial stimulation and succession following a test well injection simulating $\mathrm{CO}_{2}$ leakage into a shallow Newark Basin aquifer. PLoS One. 2015;10 (1):e0117812.

25. Bagnoud A, Chourey K, Hettich RL, De Bruijn I, Andersson AF, Leupin OX, et al. Reconstructing a hydrogen-driven microbial metabolic network in Opalinus Clay rock. Nat Commun. 2016;7:12770.

26. Daly RA, Borton MA, Wilkins MJ, Hoyt DW, Kountz DJ, Wolfe RA, et al. Microbial metabolisms in a $2.5-\mathrm{km}$-deep ecosystem created by hydraulic fracturing in shales. Nat Microbiol. 2016;1:16146.

27. Wang L-Y, Ke W-J, Sun X-B, Liu J-F, Gu J-D, Mu B-Z. Comparison of bacterial community in aqueous and oil phases of water-flooded petroleum reservoirs using pyrosequencing and clone library approaches. Appl Microbiol Biotechnol. 2014;98(9):4209-4221.

28. $\mathrm{Mu} \mathrm{A}$, Boreham $\mathrm{C}$, Leong HX, Haese RR, Moreau JW. Changes in the deep subsurface microbial biosphere resulting from a field-scale $\mathrm{CO}_{2}$ geosequestration experiment. Front Microbiol. 2014;5:209. 
29. Rajala P, Carpén L, Vepsäläinen M, Raulio M, Sohlberg E, Bomberg M. Microbially induced corrosion of carbon steel in deep groundwater environment. Front Microbiol. 2015;6:647.

30. Waldron PJ, Petsch ST, Martini AM, Nüsslein K. Salinity constraints on subsurface archaeal diversity and methanogenesis in sedimentary rock rich in organic matter. Appl Environ Microbiol. 2007;73(13):4171-4179.

31. Davis JP, Struchtemeyer CG, Elshahed MS. Bacterial communities associated with production facilities of two newly drilled thermogenic natural gas wells in the Barnett Shale (Texas, USA). Microb Ecol. 2012;64(4):942-954.

32. Murali Mohan A, Hartsock A, Hammack RW, Vidic RD, Gregory KB. Microbial communities in flowback water impoundments from hydraulic fracturing for recovery of shale gas. FEMS Microbiol Ecol. 2013;86(3):567-580.

33. Wuchter C, Banning E, Mincer TJ, Drenzek NJ, Coolen MJL. Microbial diversity and methanogenic activity of Antrim Shale formation waters from recently fractured wells. Front Microbiol. 2013;4:367.

34. Cluff MA, Hartsock A, MacRae JD, Carter K, Mouser PJ. Temporal changes in microbial ecology and geochemistry in produced water from hydraulically fractured Marcellus Shale gas wells. Environ Sci Technol. 2014;48(11):6508-6517.

35. Mohan AM, Bibby KJ, Lipus D, Hammack RW, Gregory KB. The functional potential of microbial communities in hydraulic fracturing source water and produced water from natural gas extraction characterized by metagenomic sequencing. PLoS One. 2014;9(10):e107682.

36. Akob DM, Cozzarelli IM, Dunlap DS, Rowan EL, Lorah MM. Organic and inorganic composition and microbiology of produced waters from Pennsylvania shale gas wells. Appl Geochem. 2015;60:116-125.

37. Dong Y, Kumar CG, Chia N, Kim P-J, Miller PA, Price ND, et al. Halomonas sulfidaeris-dominated microbial community inhabits a $1.8 \mathrm{~km}$-deep subsurface Cambrian Sandstone reservoir. Environ Microbiol. 2014;16(6):1695-1708.

38. Magot M, Ollivier B, Patel BKC. Microbiology of petroleum reservoirs. Antonie Van Leeuwenhoek. 2000;77(2):103-116.

39. Kryachko Y, Dong X, Sensen CW, Voordouw G. Compositions of microbial communities associated with oil and water in a mesothermic oil field. Antonie Van Leeuwenhoek. 2012;101(3):493-506.

40. Zhang F, She Y-H, Chai L-J, Banat IM, Zhang X-T, Shu F-C, et al. Microbial diversity in long-term water-flooded oil reservoirs with different in situ temperatures in China. Sci Rep. 2012;2:760.

41. Singh A, Van Hamme JD, Kuhad RC, Parmar N, Ward OP. Subsurface petroleum microbiology. In: Parmar N, Singh A eds. Geomicrobiology and Biogeochemistry. Springer, 2014, p. 153-173.

42. Voordouw G. Production-related petroleum microbiology: progress and prospects. Curr Opin Biotechnol. 2011;22(3):401-405.

43. Momper L, Reese BK, Zinke L, Wanger G, Osburn MR, Moser D, et al. Major phylum-level differences between porefluid and host rock bacterial communities in the terrestrial deep subsurface. Environ Microbiol Rep. 2017;9(5):501-511.

44. Magnabosco C, Ryan K, Lau MCY, Kuloyo O, Lollar BS, Kieft TL, et al. A metagenomic window into carbon metabolism at $3 \mathrm{~km}$ depth in Precambrian continental crust. ISME J. 2016;10(3):730-741.

45. Bomberg M, Nyyssönen M, Pitkänen P, Lehtinen A, Itävaara M. Active microbial communities inhabit sulphate-methane interphase in deep bedrock fracture fluids in Olkiluoto, Finland. Biomed Res Int. 2015;2015:979530. 
46. Osburn MR, LaRowe DE, Momper LM, Amend JP. Chemolithotrophy in the continental deep subsurface: Sanford Underground Research Facility (SURF), USA. Front Microbiol. 2014;5:610.

47. Anantharaman K, Brown CT, Hug LA, Sharon I, Castelle CJ, Probst AJ, et al. Thousands of microbial genomes shed light on interconnected biogeochemical processes in an aquifer system. Nat Commun. 2016;7:13219.

48. Purkamo L, Bomberg M, Nyyssönen M, Kukkonen I, Ahonen L, Itävaara M. Heterotrophic communities supplied by ancient organic carbon predominate in deep Fennoscandian bedrock fluids. Microb Ecol. 2015;69(2):319-332.

49. Nyyssönen M, Bomberg M, Kapanen A, Nousiainen A, Pitkänen P, Itävaara M. Methanogenic and sulphate-reducing microbial communities in deep groundwater of crystalline rock fractures in Olkiluoto, Finland. Geomicrobiol J. 2012;29 (10):863-878.

50. Momper L, Jungbluth SP, Lee MD, Amend JP. Energy and carbon metabolisms in a deep terrestrial subsurface fluid microbial community. ISME J. 2017;11 (10):2319-2333.

51. Lin L-H, Wang P-L, Rumble D, Lippmann-Pipke J, Boice E, Pratt LM, et al. Longterm sustainability of a high-energy, low-diversity crustal biome. Science. 2006;314:479-482.

52. Lau MCY, Kieft TL, Kuloyo O, Linage-Alvarez B, Van Heerden E, Lindsay MR, et al. An oligotrophic deep-subsurface community dependent on syntrophy is dominated by sulfur-driven autotrophic denitrifiers. Proc Natl Acad Sci. 2016;113(49): E7927-E7936.

53. Eydal HSC, Jägevall S, Hermansson M, Pedersen K. Bacteriophage lytic to Desulfovibrio aespoeensis isolated from deep groundwater. ISME J. 2009;3 (10):1139-1147.

54. Kyle JE, Eydal HSC, Ferris FG, Pedersen K. Viruses in granitic groundwater from 69 to $450 \mathrm{~m}$ depth of the Äspö hard rock laboratory, Sweden. ISME J. 2008;2 (5):571-574.

55. D'Hondt S, Jørgensen BB, Miller DJ, Batzke A, Blake R, Cragg BA, et al. Distributions of microbial activities in deep subseafloor sediments. Science. 2004;306 (5705):2216-2221.

56. Parkes RJ, Cragg BA, Bale SJ, Getlifff JM, Goodman K, Rochelle PA, et al. Deep bacterial biosphere in Pacific Ocean sediments. Nature. 1994;371(6496):410-413.

57. Parkes JR, Webster G, Cragg BA, Weightman AJ, Newberry CJ, Ferdelman TG, et al. Deep sub-seafloor prokaryotes stimulated at interfaces over geological time. Nature. 2005;436(7049):390-394.

58. Yanagawa K, Breuker A, Schippers A, Nishizawa M, Ijiri A, Hirai M, et al. Microbial community stratification controlled by the subseafloor fluid flow and geothermal gradient at the Iheya North hydrothermal field in the Mid-Okinawa Trough (Integrated Ocean Drilling Program Expedition 331). Appl Environ Microbiol. 2014;80 (19):6126-6135.

59. Orcutt BN, Wheat CG, Rouxel O, Hulme S, Edwards KJ, Bach W. Oxygen consumption rates in subseafloor basaltic crust derived from a reaction transport model. Nat Commun. 2013;4:2539.

60. Biddle JF, Fitz-Gibbon S, Schuster SC, Brenchley JE, House CH. Metagenomic signatures of the Peru Margin subseafloor biosphere show a genetically distinct environment. Proc Natl Acad Sci. 2008;105(30):10583-10588.

61. Orsi WD, Edgcomb VP, Christman GD, Biddle JF. Gene expression in the deep biosphere. Nature. 2013;499(7457):205-208. 
62. Orsi WD, Barker Jørgensen B, Biddle JF. Transcriptional analysis of sulfate reducing and chemolithoautotrophic sulfur oxidizing bacteria in the deep subseafloor. Environ Microbiol Rep. 2016;8(4):452-460.

63. Biddle JF, White JR, Teske AP, House CH. Metagenomics of the subsurface BrazosTrinity Basin (IODP site 1320): comparison with other sediment and pyrosequenced metagenomes. ISME J. June 6, 2011;5(6):1038-1047.

64. Newberry CJ, Webster G, Cragg BA, Parkes RJ, Weightman AJ, Fry JC. Diversity of prokaryotes and methanogenesis in deep subsurface sediments from the Nankai Trough, Ocean Drilling Program Leg 190. Environ Microbiol. 2004;6(3):274-287.

65. Inagaki F, Nunoura T, Nakagawa S, Teske A, Lever M, Lauer A, et al. Biogeographical distribution and diversity of microbes in methane hydrate-bearing deep marine sediments on the Pacific Ocean Margin. Proc Natl Acad Sci. 2006;103(8):2815-2820.

66. Biddle JF, Cardman Z, Mendlovitz H, Albert DB, Lloyd KG, Boetius A, et al. Anaerobic oxidation of methane at different temperature regimes in Guaymas Basin hydrothermal sediments. ISME J. 2012;6(5):1018-1031.

67. Teske A, Callaghan AV, LaRowe DE. Biosphere frontiers of subsurface life in the sedimented hydrothermal system of Guaymas Basin. Front Microbiol. 2014;5:1-11.

68. Marshall IPG, Karst SM, Nielsen PH, Jørgensen BB. Metagenomes from deep Baltic Sea sediments reveal how past and present environmental conditions determine microbial community composition. Mar Genomics. 2017;37:58-68.

69. Inagaki F, Hinrichs K-U, Kubo Y, Bowles MW, Heuer VB, Hong W-L, et al. Exploring deep microbial life in coal-bearing sediment down to $\sim 2.5 \mathrm{~km}$ below the ocean floor. Science. 2015;349(6246):420-424.

70. Briggs BR, Inagaki F, Morono Y, Futagami T, Huguet C, Rosell-Mele A, et al. Bacterial dominance in subseafloor sediments characterized by methane hydrates. FEMS Microbiol Ecol. 2012;81(1):88-98.

71. Walsh EA, Kirkpatrick JB, Rutherford SD, Smith DC, Sogin M, D'Hondt S. Bacterial diversity and community composition from seasurface to subseafloor. ISME J. 2016;10(4):979-989.

72. Starnawski P, Bataillon T, Ettema TJG, Jochum LM, Schreiber L, Chen X, et al. Microbial community assembly and evolution in subseafloor sediment. Proc Natl Acad Sci. 2017;114(11):2940-2945.

73. Riedinger N, Strasser M, Harris RN, Klockgether G, Lyons TW, Screaton EJ. Deep subsurface carbon cycling in the Nankai Trough (Japan) - evidence of tectonically induced stimulation of a deep microbial biosphere. Geochem Geophys Geosyst. 2015;16(9):3257-3270.

74. Arndt S, Brumsack H-J, Wirtz KW. Cretaceous black shales as active bioreactors: a biogeochemical model for the deep biosphere encountered during ODP Leg 207 (Demerara Rise). Geochim Cosmochim Acta. 2006;70(2):408-425.

75. Parkes RJ, Wellsbury P, Mather ID, Cobb SJ, Cragg BA, Hornibrook ERC, et al. Temperature activation of organic matter and minerals during burial has the potential to sustain the deep biosphere over geological timescales. Org Geochem. 2007;38 (6):845-852.

76. Lomstein BA, Langerhuus AT, D’Hondt S, Jørgensen BB, Spivack AJ. Endospore abundance, microbial growth and necromass turnover in deep sub-seafloor sediment. Nature. 2012;484(7392):101-104.

77. Contreras S, Meister P, Liu B, Prieto-Mollar X, Hinrichs K-U, Khalili A, et al. Cyclic 100-ka (glacial-interglacial) migration of subseafloor redox zonation on the Peruvian shelf. Proc Natl Acad Sci. 2013;110(45):18098-18103. 
78. Orcutt BN, Sylvan JB, Knab NJ, Edwards KJ. Microbial ecology of the dark ocean above, at, and below the seafloor. Microbiol Mol Biol Rev. 2011;75 (2):361-422.

79. Schrenk MO, Huber JA, Edwards KJ. Microbial provinces in the subseafloor. Ann Rev Mar Sci. 2009;2:85-110.

80. Colwell FS, D'Hondt S. Nature and extent of the deep biosphere. Rev Mineral Geochem. 2013;75(1):547-574.

81. Baross JA, Wilcock WSD, Kelley DS, DeLong EF, Craig Cary S. The subsurface biosphere at mid-ocean ridges: issues and challenges. In: The Subseafloor Biosphere at Mid-Ocean Ridges. American Geophysical Union, 2004, pp. 1-11.

82. Fisk M, McLoughlin N. Atlas of alteration textures in volcanic glass from the ocean basins. Geosphere. 2013;9(2):317-341.

83. Bach W, Edwards KJ. Iron and sulfide oxidation within the basaltic ocean crust: implications for chemolithoautotrophic microbial biomass production. Geochim Cosmochim Acta. 2003;67(20):3871-3887.

84. Jungbluth SP, Glavina Del Rio T, Tringe SG, Stepanauskas R, Rappé MS. Genomic comparisons of a bacterial lineage that inhabits both marine and terrestrial deep subsurface systems. PeerJ. 2017;5:e3134.

85. Nakagawa S, Inagaki F, Suzuki Y, Steinsbu BO, Lever MA, Takai K, et al. Microbial community in black rust exposed to hot ridge flank crustal fluids. Appl Environ Microbiol. 2006;72(10):6789-6799.

86. Baquiran J-PM, Ramírez GA, Haddad AG, Toner BM, Hulme S, Wheat CG, et al. Temperature and redox effect on mineral colonization in Juan de Fuca Ridge Flank subsurface crustal fluids. Front Microbiol. 2016;7:396.

87. Jungbluth SP, Grote J, Lin HT, Cowen JP, Rappé MS. Microbial diversity within basement fluids of the sediment-buried Juan de Fuca Ridge flank. ISME $J$. 2013;7(1):161-172.

88. Lever MA, Rouxel O, Alt JC, Shimizu N, Ono S, Coggon RM, et al. Evidence for microbial carbon and sulfur cycling in deeply buried ridge flank basalt. Science. 2013;339(6125):1305-1308.

89. Smith A, Popa R, Fisk M, Nielsen M, Wheat CG, Jannasch HW, et al. In situ enrichment of ocean crust microbes on igneous minerals and glasses using an osmotic flow-through device. Geochem Geophys Geosyst. 2011;12(6):Q06007.

90. Orcutt BN, Bach W, Becker K, Fisher AT, Hentscher M, Toner BM, et al. Colonization of subsurface microbial observatories deployed in young ocean crust. ISME J. 2011;5:692-703.

91. Jungbluth SP, Lin HT, Cowen JP, Glazer BT, Rappé MS. Phylogenetic diversity of microorganisms in subseafloor crustal fluids from Holes 1025C and 1026B along the Juan de Fuca Ridge flank. Front Microbiol. 2014;5:119.

92. Cowen JP, Giovannoni SJ, Kenig F, Johnson HP, Butterfield D, Rappé MS, et al. Fluids from aging ocean crust that support microbial life. Science. 2003;299 (5603):120-123.

93. Robador A, Jungbluth SP, LaRowe DE, Bowers RM, Rappé MS, Amend JP, Cowen JP. Activity and phylogenetic diversity of sulfate-reducing microorganisms in lowtemperature subsurface fluids within the upper oceanic crust. Front Microbiol. 2015;5:748.

94. Jungbluth SP, Bowers RM, Lin HT, Cowen JP, Rappé MS. Novel microbial assemblages inhabiting crustal fluids within mid-ocean ridge flank subsurface basalt. ISMEJ. 2016;10(8):2033-2047. 
95. Jungbluth SP, Amend JP, Rappé MS. Metagenome sequencing and 98 microbial genomes from Juan de Fuca Ridge flank subsurface fluids. Sci Data. 2017;4:170037.

96. Nigro L, Harris K, Orcutt B, Hyde A, Clayton-Luce S, Becker K, et al. Microbial communities at the borehole observatory on the Costa Rica Rift flank (Ocean Drilling Program Hole 896A). Front Microbiol. 2012;3:232.

97. Edwards KJ, Bach W, Kalus A. Expedition 336 Scientists. Expedition 336 Summary. College Station, TX: Ocean Drilling Program, 2012.

98. Meyer JL, Jaekel U, Tully BJ, Glazer BT, Wheat CG, Lin H-T, et al. A distinct and active bacterial community in cold oxygenated fluids circulating beneath the western flank of the Mid-Atlantic ridge. Sci Rep. 2016;6:22541.

99. Tully BJ, Wheat CG, Glazer BT, Huber JA. A dynamic microbial community with high functional redundancy inhabits the cold, oxic subseafloor aquifer. ISME $J$. 2017;12(1):1.

100. Zhang X, Fang J, Bach W, Edwards KJ, Orcutt BN, Wang F. Nitrogen stimulates the growth of subsurface basalt-associated microorganisms at the western flank of the Mid-Atlantic Ridge. Front Microbiol. 2016;7:633.

101. Zhang X, Feng X, Wang F. Diversity and metabolic potentials of subsurface crustal microorganisms from the western flank of the Mid-Atlantic Ridge. Front Microbiol. 2016;7:363.

102. Charlou JL, Donval JP, Fouquet Y, Jean-Baptiste P, Holm N. Geochemistry of high $\mathrm{H}_{2}$ and $\mathrm{CH}_{4}$ vent fluids issuing from ultramafic rocks at the Rainbow hydrothermal field (36 14' N, MAR). Chem Geol. 2002;191(4):345-359.

103. McCollom TM, Seewald JS. Abiotic synthesis of organic compounds in deep-sea hydrothermal environments. Chem Rev. 2007;107(2):382-401.

104. Proskurowski G, Lilley MD, Seewald JS, Früh-Green GL, Olson EJ, Lupton JE, et al. Abiogenic hydrocarbon production at Lost City hydrothermal field. Science. 2008;319(5863):604-607.

105. McCollom TM. Laboratory simulations of abiotic hydrocarbon formation in Earth's deep subsurface. Rev Mineral Geochem. 2013;75(1):467-494.

106. Schrenk MO, Brazelton WJ, Lang SQ. Serpentinization, carbon, and deep life. Rev Mineral Geochem. 2013;75(1):575-606.

107. Kelley DS, Karson JA, Blackman DK, Früh-Green GL, Butterfield DA, Lilley MD, et al. An off-axis hydrothermal vent field near the Mid-Atlantic Ridge at $30 \mathrm{~N}$. Nature. 2001;412(6843):145-149.

108. Kelley DS, Karson JA, Früh-Green GL, Yoerger DR, Shank TM, Butterfield DA, et al. A serpentinite-hosted ecosystem: the Lost City hydrothermal field. Science. 2005;307(5714):1428-1434.

109. Lang SQ, Butterfield DA, Schulte M, Kelley DS, Lilley MD. Elevated concentrations of formate, acetate and dissolved organic carbon found at the Lost City hydrothermal field. Geochim Cosmochim Acta. 2010;74(3):941-952.

110. Schrenk MO, Kelley DS, Bolton SA, Baross JA. Low archaeal diversity linked to subseafloor geochemical processes at the Lost City hydrothermal field, Mid-Atlantic Ridge. Environ Microbiol. 2004;6(10):1086-1095.

111. Brazelton WJ, Schrenk MO, Kelley DS, Baross JA. Methane- and sulfurmetabolizing microbial communities dominate the Lost City hydrothermal field ecosystem. Appl Environ Microbiol. 2006;72(9):6257-6270.

112. Brazelton WJ, Ludwig KA, Sogin ML, Andreishcheva EN, Kelley DS, Shen C-C, et al. Archaea and bacteria with surprising microdiversity show shifts in dominance 
over 1,000-year time scales in hydrothermal chimneys. Proc Natl Acad Sci. 2010;107 (4):1612-1617.

113. Brazelton WJ, Mehta MP, Kelley DS, Baross JA. Physiological differentiation within a single-species biofilm fueled by serpentinization. MBio. 2011;2(4):e00127-11.

114. Quesnel B, Gautier P, Boulvais P, Cathelineau M, Maurizot P, Cluzel D, et al. Syntectonic, meteoric water-derived carbonation of the New Caledonia peridotite nappe. Geology. 2013;41(10):1063-1066.

115. Quéméneur M, Bes M, Postec A, Mei N, Hamelin J, Monnin C, et al. Spatial distribution of microbial communities in the shallow submarine alkaline hydrothermal field of the Prony Bay, New Caledonia. Environ Microbiol Rep. 2014;6 (6):665-674.

116. Postec A, Quéméneur M, Bes M, Mei N, Benaïssa F, Payri C, et al. Microbial diversity in a submarine carbonate edifice from the serpentinizing hydrothermal system of the Prony Bay (New Caledonia) over a 6-year period. Front Microbiol. 2015;6:857.

117. Morrill PL, Kuenen JG, Johnson OJ, Suzuki S, Rietze A, Sessions AL, et al. Geochemistry and geobiology of a present-day serpentinization site in California: The Cedars. Geochim Cosmochim Acta. 2013;109:222-240.

118. Szponar N, Brazelton WJ, Schrenk MO, Bower DM, Steele A, Morrill PL. Geochemistry of a continental site of serpentinization, the Tablelands Ophiolite, Gros Morne National Park: a Mars analogue. Icarus. 2013;224:286-296.

119. Brazelton WJ, Nelson B, Schrenk MO. Metagenomic evidence for $\mathrm{H}_{2}$ oxidation and $\mathrm{H}_{2}$ production by serpentinite-hosted subsurface microbial communities. Front Microbiol. 2012;2:268.

120. Brazelton WJ, Morrill PL, Szponar N, Schrenk MO. Bacterial communities associated with subsurface geochemical processes in continental serpentinite springs. Appl Environ Microbiol. 2013;79:3906-3916.

121. Tiago I, Veríssimo A. Microbial and functional diversity of a subterrestrial high pH groundwater associated to serpentinization. Environ Microbiol. 2013;15: 1687-1706.

122. Suzuki S, Ishii S, Wu A, Cheung A, Tenney A, Wanger G, et al. Microbial diversity in The Cedars, an ultrabasic, ultrareducing, and low salinity serpentinizing ecosystem. Proc Natl Acad Sci. 2013;110(38):15336-15341.

123. Suzuki S, Kuenen JG, Schipper K, Van Der Velde S, Ishii S, Wu A, et al. Physiological and genomic features of highly alkaliphilic hydrogen-utilizing Betaproteobacteria from a continental serpentinizing site. Nat Commun. 2014;5:3900.

124. Twing KI, Brazelton WJ, Kubo MDY, Hyer AJ, Cardace D, Hoehler TM, et al. Serpentinization-influenced groundwater harbors extremely low diversity microbial communities adapted to high pH. Front Microbiol. 2017;8:308.

125. Opatkiewicz AD, Butterfield DA, Baross JA. Individual hydrothermal vents at Axial Seamount harbor distinct subseafloor microbial communities. FEMS Microbiol Ecol. 2009;70(3):413-424.

126. Niemann H, Lösekann T, De Beer D, Elvert M, Nadalig T, Knittel K. Novel microbial communities of the Haakon Mosby mud volcano and their role as a methane sink. Nature. 2006;443(7113):854.

127. Ruff SE, Biddle JF, Teske AP, Knittel K, Boetius A, Ramette A. Global dispersion and local diversification of the methane seep microbiome. Proc Natl Acad Sci. 2015;112(13):4015-4020. 
128. Quéméneur M, Palvadeau A, Postec A, Monnin C, Chavagnac V, Ollivier B, et al. Endolithic microbial communities in carbonate precipitates from serpentinite-hosted hyperalkaline springs of the Voltri Massif (Ligurian Alps, Northern Italy). Environ Sci Pollut Res. 2015;22(18):13613-13624.

129. Brazelton WJ, Thornton CN, Hyer A, Twing KI, Longino AA, Lang SQ, et al. Metagenomic identification of active methanogens and methanotrophs in serpentinite springs of the Voltri Massif, Italy. PeerJ. 2017;5:e2945.

130. Crespo-Medina M, Twing KI, Sánchez-Murillo R, Brazelton WJ, McCollom TM, Schrenk MO. Methane dynamics in a tropical serpentinizing environment: the Santa Elena Ophiolite, Costa Rica. Front Microbiol. 2017;8:916.

131. Cardace D, Hoehler T, McCollom T, Schrenk M, Carnevale D, Kubo M, et al. Establishment of the Coast Range ophiolite microbial observatory (CROMO): drilling objectives and preliminary outcomes. Sci Drill. 2013;16:45-55.

132. Daae FL, Økland I, Dahle H, Jørgensen SL, Thorseth IH, Pedersen RB. Microbial life associated with low-temperature alteration of ultramafic rocks in the Leka ophiolite complex. Geobiology. 2013;11(4):318-339.

133. NERC. Oman Drilling Project. www.omandrilling.ac.uk, 2017.

134. Früh-Green GL, Orcutt BN, Green SL, Cotterill C, Morgan S, Akizawa N, et al. Expedition 357 summary. Proc Int Ocean Discov Progr. 2017;357.

135. Higashi Y, Sunamura M, Kitamura K, Nakamura K, Kurusu Y, Ishibashi J, et al. Microbial diversity in hydrothermal surface to subsurface environments of Suiyo Seamount, Izu-Bonin Arc, using a catheter-type in situ growth chamber. FEMS Microbiol Ecol. 2004;47(3):327-336.

136. Opatkiewicz AD, Butterfield DA, Baross JA. Individual hydrothermal vents at Axial Seamount harbor distinct subseafloor microbial communities. FEMS Microbiol Ecol. 2009;70(3):413-424.

137. Fernández-Remolar DC, Prieto-Ballesteros O, Rodríguez N, Gómez F, Amils R, Gómez-Elvira $\mathrm{J}$, et al. Underground habitats in the Rio Tinto basin: a model for subsurface life habitats on Mars. Astrobiology. 2008;8(5):1023-1047.

138. Carrier BL. Next steps forward in understanding Martian surface and subsurface chemistry. J Geophys Res Planets. 2017;122(9):1951-1953.

139. Michalski JR, Cuadros J, Niles PB, Parnell J, Rogers AD, Wright SP. Groundwater activity on Mars and implications for a deep biosphere. Nat Geosci. 2013; 6(2):133.

140. Waite JH, Glein CR, Perryman RS, Teolis BD, Magee BA, Miller G, et al. Cassini finds molecular hydrogen in the Enceladus plume: evidence for hydrothermal processes. Science. 2017;356(6334):155-159.

141. Flynn GJ. The delivery of organic matter from asteroids and comets to the early surface of Mars. In: Rickman H, Valtonen MJ, ed. Worlds in Interaction: Small Bodies and Planets of the Solar System. Springer, 1996, pp. 469-474.

142. Field CB, Behrenfeld MJ, Randerson JT, Falkowski P. Primary production of the biosphere: integrating terrestrial and oceanic components. Science. 1998;281(5374): 237-240.

143. Sherwood Lollar B, Voglesonger K, Lin L-H, Lacrampe-Couloume G, Telling J, Abrajano TA, et al. Hydrogeologic controls on episodic $\mathrm{H} 2$ release from Precambrian fractured rocks - energy for deep subsurface life on Earth and Mars. Astrobiology. 2007;7(6):971-986.

144. Kattenhorn SA, Prockter LM. Evidence for subduction in the ice shell of Europa. Nat Geosci. 2014;7(10):762. 
145. Waite JH, Combi MR, Ip W-H, Cravens TE, McNutt RL, Kasprzak W, et al. Cassini ion and neutral mass spectrometer: Enceladus plume composition and structure. Science. 2006;311(5766):1419-1422.

146. Karner MB, DeLong EF, Karl DM. Archaeal dominance in the mesopelagic zone of the Pacific Ocean. Nature. 2001;409(6819):507.

147. Biddle JF, Lipp JS, Lever MA, Lloyd KG, Sørensen KB, Anderson R, et al. Heterotrophic archaea dominate sedimentary subsurface ecosystems off Peru. Proc Natl Acad Sci. 2006;103(10):3846-3851.

148. Lipp JS, Morono Y, Inagaki F, Hinrichs K-U. Significant contribution of Archaea to extant biomass in marine subsurface sediments. Nature. 2008;454(7207):991-994.

149. Schouten S, Middelburg JJ, Hopmans EC, Sinninghe Damsté JS. Fossilization and degradation of intact polar lipids in deep subsurface sediments: a theoretical approach. Geochim Cosmochim Acta. 2010;74(13):3806-3814.

150. Lloyd KG, May MK, Kevorkian RT, Steen AD. Meta-analysis of quantification methods shows that archaea and bacteria have similar abundances in the subseafloor. Appl Environ Microbiol. 2013;79(24):7790-7799.

151. Chen X, Andersen TJ, Morono Y, Inagaki F, Jørgensen BB, Lever MA. Bioturbation as a key driver behind the dominance of bacteria over archaea in near-surface sediment. Sci Rep. 2017;7(1):2400.

152. Katayama T, Yoshioka H, Muramoto Y, Usami J, Fujiwara K, Yoshida S, et al. Physicochemical impacts associated with natural gas development on methanogenesis in deep sand aquifers. ISME J. 2015;9(2):436-446.

153. Simkus DN, Slater GF, Lollar BS, Wilkie K, Kieft TL, Magnabosco C, et al. Variations in microbial carbon sources and cycling in the deep continental subsurface. Geochim Cosmochim Acta. 2016;173:264-283.

154. Baker BJ, Saw JH, Lind AE, Lazar CS, Hinrichs K-U, Teske AP, et al. Genomic inference of the metabolism of cosmopolitan subsurface Archaea, Hadesarchaea. Nat Microbiol. 2016;1:16002.

155. Brown CT, Hug LA, Thomas BC, Sharon I, Castelle CJ, Singh A, et al. Unusual biology across a group comprising more than $15 \%$ of domain Bacteria. Nature. 2015;523(7559):208.

156. Hug LA, Baker BJ, Anantharaman K, Brown CT, Probst AJ, Castelle CJ, et al. A new view of the tree of life. Nat Microbiol. 2016;1:16048.

157. Reysenbach A-L, Liu Y, Banta AB, Beveridge TJ, Kirshtein JD, Schouten S, et al. A ubiquitous thermoacidophilic archaeon from deep-sea hydrothermal vents. Nature. 2006;442(7101):444.

158. Knittel K, Boetius A. Anaerobic oxidation of methane: progress with an unknown process. Annu Rev Microbiol. 2009;63:311-334.

159. Skennerton CT, Chourey K, Iyer R, Hettich RL, Tyson GW, Orphan VJ. Methanefueled syntrophy through extracellular electron transfer: uncovering the genomic traits conserved within diverse bacterial partners of anaerobic methanotrophic archaea. MBio. 2017;8(4):e00530-17.

160. Topçuoğlu BD, Stewart LC, Morrison HG, Butterfield DA, Huber JA, Holden JF. Hydrogen limitation and syntrophic growth among natural assemblages of thermophilic methanogens at deep-sea hydrothermal vents. Front Microbiol. 2016;7:1240.

161. Probst AJ, Ladd B, Jarett JK, Geller-McGrath DE, Sieber CMK, Emerson JB, et al. Differential depth distribution of microbial function and putative symbionts through sediment-hosted aquifers in the deep terrestrial subsurface. Nat Microbiol. 2018;3(3):328. 
162. Borgonie G, García-Moyano A, Litthauer D, Bert W, Bester A, van Heerden E, et al. Nematoda from the terrestrial deep subsurface of South Africa. Nature. 2011;474:79-82.

163. Allen SE. Horizontal Gene Transfer as a Mechanism of Adaptation to an Extreme Subterranean Environment by the Nematode Halicephalobus mephisto. American University, 2017.

164. Borgonie G, Linage-Alvarez B, Ojo AO, Mundle SOC, Freese LB, Van Rooyen C, et al. Eukaryotic opportunists dominate the deep-subsurface biosphere in South Africa. Nat Commun. 2015;6:8952.

165. Borgonie G, Magnabosco C, Garcia-Moyano A, Linage-Alvarez B, Ojo AO, Freese LB, et al. New ecosystems in the deep subsurface follow the flow of water driven by geological activity. Sci Rep. 2019;9:3310.

166. Pedersen K. Preliminary Investigations of Deep Ground Water Microbiology in Swedish Granitic Rock. Svensk Kärnbränslehantering, 1988.

167. Pedersen K, Arlinger J, Ekendahl S, Hallbeck L. 16S rRNA gene diversity of attached and unattached bacteria in boreholes along the access tunnel to the Äspö hard rock laboratory, Sweden. 1996;19(4):249-262.

168. Palumbo AV, Zhang C, Liu S, Scarborough SP, Pfiffner SM, Phelps TJ. Influence of media on measurement of bacterial populations in the subsurface. Appl Biochem Biotechnol. 1996;57(1):905.

169. Ekendahl S, O'neill AH, Thomsson E, Pedersen K. Characterisation of yeasts isolated from deep igneous rock aquifers of the Fennoscandian Shield. Microb Ecol. 2003;46(4):416-428.

170. Sohlberg E, Bomberg M, Miettinen H, Nyyssönen M, Salavirta H, Vikman M, et al. Revealing the unexplored fungal communities in deep groundwater of crystalline bedrock fracture zones in Olkiluoto, Finland. Front Microbiol. 2015;6:573.

171. Sinclair JL, Ghiorse WC. Distribution of aerobic bacteria, protozoa, algae, and fungi in deep subsurface sediments. Geomicrobiol J. 1989;7(1-2):15-31.

172. Raghukumar C, Raghukumar S, Sheelu G, Gupta SM, Nagender Nath B, Rao BR. Buried in time: culturable fungi in a deep-sea sediment core from the Chagos Trench, Indian Ocean. Deep Sea Res Part I Oceanogr Res Pap. 2004;51(11):1759-1768.

173. Edgcomb VP, Beaudoin D, Gast R, Biddle JF, Teske A. Marine subsurface eukaryotes: the fungal majority. Environ Microbiol. 2011;13(1):172-183.

174. Orsi W, Biddle JF, Edgcomb V. Deep sequencing of subseafloor eukaryotic rRNA reveals active fungi across marine subsurface provinces. PLoS One. 2013;8(2): e56335.

175. Ivarsson M, Bengtson S, Skogby H, Lazor P, Broman C, Belivanova V, Marone F. A fungal-prokaryotic consortium at the basalt-zeolite interface in subseafloor igneous crust. PLoS One. 2015;10(10):e0140106.

176. Ivarsson M, Schnürer A, Bengtson S, Neubeck A. Anaerobic fungi: a potential source of biological $\mathrm{H}_{2}$ in the oceanic crust. Front Microbiol. 2016;7:674.

177. Drake H, Ivarsson M, Bengtson S, Heim C, Siljeström S, Whitehouse MJ, et al. Anaerobic consortia of fungi and sulfate reducing bacteria in deep granite fractures. Nat Commun. 2017;8(1):55.

178. Suttle CA. Marine viruses - major players in the global ecosystem. Nat Rev Microbiol. 2007;5(10):801-812.

179. Suttle CA. Viruses in the sea. Nature. 2005;437(7057):356.

180. Anderson RE, Brazelton WJ, Baross J. Is the genetic landscape of the deep subsurface biosphere affected by viruses? Front Microbiol. 2011;2:219. 
181. Anderson RE, Brazelton WJ, Baross JA. The deep viriosphere: assessing the viral impact on microbial community dynamics in the deep subsurface. Rev Mineral Geochem. 2013;75:649-675.

182. Jørgensen BB, Marshall IPG. Slow microbial life in the seabed. Ann Rev Mar Sci. 2016;8:311-332.

183. Bird DF, Juniper SK, Ricciardi-Rigault M, Martineu P, Prairie YT, Calvert SE. Subsurface viruses and bacteria in Holocene/Late Pleistocene sediments of Saanich Inlet, BC: ODP holes 1033b and 1034b, Leg 169s. Mar Geol. 2001;174(1):227-239.

184. Middelboe M, Glud RN, Filippini M. Viral abundance and activity in the deep subseafloor biosphere. Aquat Microb Ecol. 2011;63:1-8.

185. Engelhardt T, Kallmeyer J, Cypionka H, Engelen B. High virus-to-cell ratios indicate ongoing production of viruses in deep subsurface sediments. ISME J. 2014;8 (7):1503-1509.

186. Knowles B, Silveira CB, Bailey BA, Barott K, Cantu VA, Cobián-Güemes AG, et al. Lytic to temperate switching of viral communities. Nature. 2016;531(7595):466.

187. Labonté JM, Field EK, Lau M, Chivian D, Van Heerden E, Wommack KE, et al. Single cell genomics indicates horizontal gene transfer and viral infections in a deep subsurface Firmicutes population. Front Microbiol. 2015;6:349.

188. Engelhardt T, Sahlberg M, Cypionka H, Engelen B. Induction of prophages from deep-subseafloor bacteria. Environ Microbiol Rep. 2011;3(4):459-465.

189. Nigro OD, Jungbluth SP, Lin HT, Hsieh CC, Miranda JA, Schvarcz CR, et al. Viruses in the ocean basement. MBio. 2017;8(2):e02129-16.

190. Labonte JM, Lever MA, Edward KJ, Orcutt BN. Influence of igneous basement on deep sediment microbial diversity on the eastern Juan de Fuca Ridge flank. Front Microbiol. 2017;8:1434.

191. Fredrickson JK, McKinley JP, Bjornstad BN, Long PE, Ringelberg DB, White DC, et al. Pore-size constraints on the activity and survival of subsurface bacteria in a late cretaceous shale-sandstone sequence, northwestern New Mexico. Geomicrobiol J. 1997;14(3):183-202.

192. Rebata-Landa V, Santamarina JC. Mechanical limits to microbial activity in deep sediments. Geochem Geophys Geosyst. 2006;7(11):Q11006.

193. Cockell CS, Voytek MA, Gronstal AL, Finster K, Kirshtein JD, Howard K, et al. Impact disruption and recovery of the deep subsurface biosphere. Astrobiology. 2012;12(3):231-246.

194. Scheibe TD, Hubbard SS, Onstott TC, DeFlaun MF. Lessons learned from bacterial transport research at the South Oyster Site. Groundwater. 2011;49:745-763.

195. Bell E, Blake LI, Sherry A, Head IM, Hubert CRJ. Distribution of thermophilic endospores in a temperate estuary indicate that dispersal history structures sediment microbial communities. Environ Microbiol. 2018;20(3):1134-1147.

196. Chakraborty A, Ellefson E, Li C, Gittins D, Brooks JM, Bernard BB, et al. Thermophilic endospores associated with migrated thermogenic hydrocarbons in deep Gulf of Mexico marine sediments. ISME J. 2018;1:1895-1906.

197. Nakagawa T, Takai K, Suzuki Y, Hirayama H, Konno U, Tsunogai U, et al. Geomicrobiological exploration and characterization of a novel deep-sea hydrothermal system at the TOTO caldera in the Mariana Volcanic Arc. Environ Microbiol. 2006;8(1):37-49.

198. Blank JG, Green SJ, Blake D, Valley JW, Kita NT, Treiman A, et al. An alkaline spring system within the Del Puerto Ophiolite (California, USA): a Mars analog site. Planet Space Sci. 2009;57(5-6):533-540. 
199. Takai K, Moyer CL, Miyazaki M, Nogi Y, Hirayama H, Nealson KH, et al. Marinobacter alkaliphilus sp. nov., a novel alkaliphilic bacterium isolated from subseafloor alkaline serpentine mud from Ocean Drilling Program Site 1200 at South Chamorro Seamount, Mariana Forearc. Extremophiles. 2005;9(1):17-27.

200. Antunes A, Taborda M, Huber R, Moissl C, Nobre MF, da Costa MS. Halorhabdus tiamatea sp. nov., a non-pigmented, extremely halophilic archaeon from a deep-sea, hypersaline anoxic basin of the Red Sea, and emended description of the genus Halorhabdus. Int J Syst Evol Microbiol. 2008;58(1):215-220.

201. Hallsworth JE, Yakimov MM, Golyshin PN, Gillion JLM, D’Auria G, de Lima Alves $\mathrm{F}$, et al. Limits of life in $\mathrm{MgCl}_{2}$-containing environments: chaotropicity defines the window. Environ Microbiol. 2007;9(3):801-813.

202. Colwell FS, Smith RP. Unifying principles of the deep terrestrial and deep marine biospheres. In Subseafloor Biosph Mid-Ocean Ridges. American Geophysical Union, 2004, pp. 355-367.

203. Amend JP, Teske A. Expanding frontiers in deep subsurface microbiology. Palaeogeogr Palaeoclimatol Palaeoecol. 2005;219:131-155.

204. Cragg BA, Summit M, Parkes RJ. Bacterial profiles in a sulphide mount (site 1035) and an area of active fluid venting (site 1036) in hot hydrothermal sediments from Middle Valley (Northeast Pacific). In: Zierenberg RA, Fouquet Y, Miller DJ, Normak WR, eds. Proceedings of the Ocean Drilling Program, Scientific Results Volume 169. College Station, TX: Ocean Drilling Program, 2000, pp. 1-18.

205. Daniel RM, Cowan DA. Biomolecular stability and life at high temperatures. Cell Mol Life Sci C. 2000;57(2):250-264.

206. Baker-Austin C, Dopson M. Life in acid: $\mathrm{pH}$ homeostasis in acidophiles. Trends Microbiol. 2007;15(4):165-171.

207. Bartlett DH. Pressure effects on in vivo microbial processes. Biochim Biophys Acta. 2002;1595(1-2):367-381.

208. Hazael R, Meersman F, Ono F, McMillan PF. Pressure as a limiting factor for life. Life. 2016;6(3):34.

209. Nesbø CL, Swithers KS, Dahle H, Haverkamp THA, Birkeland N-K, Sokolova T, et al. Evidence for extensive gene flow and Thermotoga subpopulations in subsurface and marine environments. ISME J. 2015;9(7):1532.

210. Starnawski P, Bataillon T, Ettema TJG, Jochum LM, Schreiber L, Chen X, et al. Microbial community assembly and evolution in subseafloor sediment. Proc Natl Acad Sci. 2017;114(11):2940-2945.

211. Anderson RE, Reveillaud J, Reddington E, Delmont TO, Eren AM, McDermott JM, et al. Genomic variation in microbial populations inhabiting the marine subseafloor at deep-sea hydrothermal vents. Nat Commun. 2017;8(1):1114.

212. Momper L, Magnabosco C, Hu E, Amend J, Fournier GP. Genomic evidence of chemotrophic metabolisms in deep-dwelling Chloroflexi conferred by ancient horizontal gene transfer events. American Geophysical Union, Fall Meeting. 2017;B14D-07.

213. Novichkov PS, Wolf YI, Dubchak I, Koonin EV. Trends in prokaryotic evolution revealed by comparison of closely related bacterial and archaeal genomes. J Bacteriol. 2009;191(1):65-73.

214. Lynch M, Conery JS. The origins of genome complexity. Science. 2003;302 (5649):1401-1404.

215. Kuo C-H, Moran NA, Ochman H. The consequences of genetic drift for bacterial genome complexity. Genome Res. 2009;19(8):1450-1454. 
216. Brazelton WJ, Baross JA. Abundant transposases encoded by the metagenome of a hydrothermal chimney biofilm. ISME J. 2009;3(12):1420-1424.

217. Paul BG, Bagby SC, Czornyj E, Arambula D, Handa S, Sczyrba A, et al. Targeted diversity generation by intraterrestrial archaea and archaeal viruses. Nat Commun. 2015;6:6585.

218. Paul BG, Burstein D, Castelle CJ, Handa S, Arambula D, Czornyj E, et al. Retroelement-guided protein diversification abounds in vast lineages of Bacteria and Archaea. Nat Microbiol. 2017;2:17045.

219. Phelps TJ, Fliermans CB, Garland TR, Pfiffner SM, White DC. Methods for recovery of deep terrestrial subsurface sediments for microbiological studies. J Microbiol Methods. 1989;9(4):267-279.

220. Sheik CS, Reese BK, Twing KI, Sylvan JB, Grim SL, Schrenk MO, et al. Identification and removal of contaminant sequences from ribosomal gene databases: lessons from the Census of Deep Life. Front Microbiol. 2018;9:840.

221. Payler SJ, Biddle JF, Lollar BS, Fox-Powell MG, Edwards T, Ngwenya BT, et al. An ionic limit to life in the deep subsurface. Front Microbiol. 2019;10:426. 